\title{
Claude Thiry, Le printemps des temps nouveaux
}

\section{Pietro Arioli}

\section{(2) OpenEdition}

\section{Journals}

\section{Édition électronique}

URL : http://journals.openedition.org/studifrancesi/7480

DOI : 10.4000/studifrancesi.7480

ISSN : 2427-5856

\section{Éditeur}

Rosenberg \& Sellier

\section{Édition imprimée}

Date de publication : 1 décembre 2009

Pagination : 604-605

ISSN : 0039-2944

\section{Référence électronique}

Pietro Arioli, «Claude Thiry, Le printemps des temps nouveaux », Studi Francesi [En ligne], 159 (LIII | III) | 2009, mis en ligne le 30 novembre 2015, consulté le 09 janvier 2021. URL : http://

journals.openedition.org/studifrancesi/7480; DOI : https://doi.org/10.4000/studifrancesi.7480

Ce document a été généré automatiquement le 9 janvier 2021.

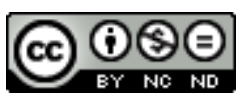

Studi Francesi è distribuita con Licenza Creative Commons Attribuzione - Non commerciale - Non opere derivate 4.0 Internazionale. 


\title{
Claude Thiry, Le printemps des temps
}

\section{nouveaux}

\author{
Pietro Arioli
}

\section{RÉFÉRENCE}

CLAUDE THIRY, Le printemps des temps nouveaux, dans Autour du XV siècle. Journées

d'études en l'honneur d'Alberto Vàrvaro, éd. par Paola MORENo et Giovanni PALUMBO, Bibliothèque de la Faculté de Philosophie et Lettres de l'Université de Liège, (Fascicule CCXCII), Diffusion Droz, Genève, 2008, pp. 219-228.

1 Claude Thiry conteste l'étiquette d'«automne» attribuée aux derniers siècles du Moyen Âge par quelques historiens, premier parmi tous Johan Huizinga. Les XIV et $\mathrm{Xv}^{\mathrm{e}}$ siècles auraient constitué, en fait, «le printemps des temps nouveaux» (d'où le titre de l'article) et non pas une époque de déclin et de flétrissure, comme Huizinga semble le suggérer. Pourtant, le problème n'est pas seulement dénominatif: en effet, un encadrement incorrect peut influencer et fausser la compréhension d'une époque tout entière. Cl. Thiry porte de nombreux exemples à l'appui de sa thèse, tirés de la production littéraire: poésie lyrique, théâtre, récit bref, mises en proses, chroniques historiques. Pour chaque genre, il démontre que la production la plus intéressante à la lumière de l'évolution littéraire successive remonte justement à ce qui a été appelé jusqu'ici l'«automne» du Moyen Âge (plutôt qu'à son «été») et propose donc un véritable renversement de perspective. 